\title{
What would Ron choose from the Islamic basket? Notes on Scientology's construction of Islam ${ }^{1}$
}

\author{
STEFANO BIGLIARDI \\ Monterrey Tech CSF Mexico City
}

\begin{abstract}
Two theological claims characterizing Scientology are its continuity with older religions, and its support for religious freedom and pluralism. This article, focusing on two articles that appeared in the magazine Advance! in the 1970s as well as other pieces authored by L. R. Hubbard, analyses Scientology's narrative about Islam following Jan Hjärpe's ‘basket theory'.
\end{abstract}

Keywords: Scientology; Scientology and Islam; L. Ron Hubbard and Islam; Scientology and other religions; Jan Hjärpe

In 'What Will Be Chosen from the Islamic Basket?' (Hjärpe 1997) the Islamologist Jan Hjärpe defines religion as fulfilling a psychological-cognitive role: it offers 'quietude in crises' and 'perceptional patterns' through which experience is filtered (Hjärpe 1997, 267); he states that a religious identity is shaped within a major tradition and/or in contrast with other religions by using a selection among the different 'items' of a 'basket' or '[...] the set-up area of traditions in the specific religion or ideology, as we can find it in its activities, i.e. all the rituals, narratives, historiography, categorizations, terminology and observances.' (Hjärpe 1997, 267.) Such a 'basket' can be used blindly and passively, and can refer both to the construction on part of those who belong to a religion or by external observers. Doctrine and theology, suggests Hjärpe, 'have very much the function of a 'border defence'

1 Acknowledgements. This article was inspired by my participation in the 2014 CESNUR Conference on New Religious Movements at Baylor University, Texas (June 4-7). I warmly thank Stephen Kent, Alexis Brown, and Hugh Urban, who helped me to collect Advance! issues and Scientology texts relevant to the topic, and who provided me with useful advice. Likewise I thank William Burke and Jefferson Hawkins, as well as an anonymous ex-Scientologist whom I communicated with through the Web site Operation Clambake, for their insights about the magazine as well as Scientology and Islam. My warmest thanks go to Olof Heilo for helping me with the interpretation of several pictures, to Anne Ross Solberg for the collection and translation of articles regarding Scientology in Turkey, and Liesl Drew for her assistance with proofreading. I also thank two anonymous reviewers who helped me to clarify my views and steered me away from several mistakes and inaccuracies. My pages are dedicated to Ulrika Mårtensson for being so open-minded to support an article about Scientology and Islam. 
[...] which uses material from the basket' (Hjärpe 1997, 268). In other words Hjärpe invites us to see the pragmatic and social function of the concepts used in characterizing a specific religion, and points out that a creative intellectual enterprise such as the development of a theology is not immune to such functionality. Finally, with the image of different 'items' Hjärpe teaches us that a specific religion's (self-)narrative should not be taken as a monolithic whole; the function of each and every element composing it should be individually analysed, while not losing sight of the fact that all the 'items' are placed in one and the same 'basket'.

This article employs Hjärpe's theory to analyse a special case: the construction of Islam within Scientology. This is mainly examined with reference to two issues of the magazine Advance! that hosted pieces about Islam and pictures authored by the founder of Scientology, as well as other texts of his that touched upon Islam. Reference is also made to Scientology's more recent relationship with Islam and Islam-related events and institutions.

The theological relationship, past or potential, between Scientology and Islam is an almost un-investigated topic. My interpretation addresses three interrelated questions, two of them more historical in character: what perception of Islam could the founder of Scientology have, and what representation of Islam could he promote? The third question is more related to the present: if they are not to invent theological doctrines ex novo, but rather draw upon the claims of Scientology's founder, how can Scientologists found and justify a compatibility or friendly relationship with Islam? Such necessity might arise for instance for an individual with a relationship to Islam who self-identifies with Scientology, or for Scientology taken as an organization, while presenting themselves as credible partners in interreligious dialogue or trying to recruit new members in a community influenced by Islam.

\section{Dianetics and scientology}

Hugh B. Urban describes Scientology as a 'controversial movement' with a 'complex, tangled, and often tortuous history' (Urban 2011,3). The purpose of this paper is neither to solve controversies nor to reconstruct Scientology's history in detail, but to contribute to the analysis and evaluation of a fragment of its theology from a viewpoint neither complacent nor polemical towards Scientology's self-narratives. For this purpose it will suffice to recall only the most general aspects of its development and doctrines.

The initiatives and teachings that founded and are still constitutive of Scientology stem from the creativity of a prolific science-fiction author, the 
American Lafayette Ron Hubbard (1911-1986), still lovingly referred to by Scientologists as 'Ron'. Hubbard, whom Urban describes as an 'American entrepreneur' and 'spiritual bricoleur' (Urban 2011, 26), invented a selfhelp psychological method called Dianetics (from the ancient Greek terms for 'through' and 'knowledge'), which he first explained in an article in a science-fiction magazine in May 1950, and in another volume later that year (Hubbard 1950a; Hubbard 1950b). Dianetics is based on the thesis that the human mind is impaired by engrams or mnemonic traces of traumatic experiences. The passive part of the mind where they are stored is called reactive, as opposed to the active part or analytical mind (CSI 1998, 16). Through a procedure called auditing (from the Latin verb for 'listening') applied from 1952 onward by means of a device called the Electropsychometer (or EMeter, patented - though not invented - by Hubbard; see Wallis 1976, 116 and Urban 2011, 49-52), these engrams could be identified and eliminated, leading to the drastic improvement of a person's potential for action and success (cf. CSI 1998, 33-7).

Early on, Hubbard faced intertwined challenges with the recognition, doctrinal integrity, and financial success of Dianetics. The medical establishment from which he initially sought approval did not accept his theories (see Wallis 1976, 23). When they gained more visibility, they were criticized as pseudoscientific/pseudomedical (see Urban 2011, 64-66). Finally, practitioners begun discussing ways in which to invent and implement their own variants of Dianetics (see Wallis 1976, 81). With a series of practical initiatives, among the most important being the incorporation of three new organizations in December 1953 in Camden, NJ (the Church of Scientology, the Church of American Science, and the Church of Spiritual Engineering - see Urban 2011, 65), Hubbard bestowed on Dianetics the characteristics of a religion.

Scientology (from the Latin term for 'knowledge' and the Greek suffix denoting 'study') encapsulated Dianetics in a broader conceptual system. The human soul was defined as thetan (from the ancient Greek letter theta, representing 'life force'), as a spiritual unity that goes through a process of successive (human) incarnations (cf. CSI 1998, 17-18). The engrams were attributed to traumatic experiences undergone in earlier lives, dating back millions of years. The thetans' collective vicissitudes were absorbed in a space-opera grand narrative whose details were to be gradually revealed to Scientologists according to their advancement on the path of improvement, called the Bridge to Total Freedom (cf. CSI 1998, 31, 56). The phases of such advancement through auditing were elaborated in great detail, together with 
hierarchies, procedures, and prices. An individual before liberation from the content of the reactive mind is described as pre-clear; a liberated one, as clear (cf. CSI 1998, 37). One of the higher stages in the bridge is called Operating Thetan or OT, and is said to be able to control matter, energy, space, and time, or MEST (cf. CSI 1998, 18, 37, 55, 104-9), which otherwise entrap thetans. ${ }^{2}$ Scientology also contains a meticulously numbered taxonomy of emotions called tone levels (see Harley and Kieffer 2009, 194-5). Another theory concerns the eight dynamics or dimensions of survival, the eighth one being the Supreme Being or God (cf. CSI 1998, 22-26). The psychiatric establishment became a major polemical target; Hubbard attacked it for being unscientific and inhumanly abusive (see Rothstein 2009, 381).

Notwithstanding international legal problems that forced Hubbard to establish his headquarters on a small fleet constantly on the move, he nourished the Church's doctrines and practices through an inexhaustible production of books, articles, and lectures as well as periodical publications which he controlled. ${ }^{3}$ The dissemination and recruitment strategies became increasingly refined, including the involvement of celebrities and the usage of front groups presented as fighting against violations of human rights or drug addictions.

Hubbard established ceremonies such as marriage and funeral that, like those of other religions, mark an individual's and a community's most important and emotionally-laden biographical events (cf. CSI 1998, 41-34); furthermore, he decided on the adoption of symbols such as a special $\operatorname{cross}^{5}$ and priestly collars, and terms creating or emphasizing Scientology's similarity with already existent religions (e.g. auditing was called pastoral care and local organizations missions - cf. CSI 1998, 61). However Scientology was also given its own distinctive terminology, which its practitioners should gradually master (Hubbard's neologisms have been estimated in the hundreds - see Wallis 1976, 231) and which would mark its special identity.

After Hubbard's death, the leadership was assumed by David Miscavige (b. 1960), currently Chairman of the Board of the Religious Technology Center, which manages the trademarks and copyrights of Dianetics and Scientology (cf. CSI 1998, 71). The figure of Hubbard has been divinized

2 I italicize the terms since Hubbard characterized them in an idiosyncratic way both far from commonsensical and physical usage so that they can be assumed to be Scientology jargon.

3 For a discussion of Hubbard's authorship and the related problems see Christensen 2009b.

4 Dericquebourg 2009 describes in detail the ceremonies yet also recognizes that they are neither regularly held nor well attended (a fact explained with the centrality of auditing rather than any other activity).

5 Scientology's cross has four rays symbolizing, together with the arms, the eight dynamics (cf. CSI 1998, 52-4). 
and, faithful to his strenuous attempts at keeping the doctrines fixed and immutable, no theological shifts or changes have been introduced; one of the tenets of Scientology is that, since Hubbard's accomplishments were perfect, no deviation is able to obtain the same results and therefore all critical discussion or creative elaboration is prohibited (see Wallis 1976, 230).

A major success achieved by Scientology after Hubbard's death was its formal recognition as a religion (entailing tax exemption) by the US Internal Revenue Service on October 1, 1993 (cf. CSI 1998, 237). Scientology officially claims millions of adherents worldwide and skyrocketing figures. However, both anti-Scientology activists and some scholars have suggested that such numbers are inflated, e.g. by counting people who have even only once made an expression of interest, and that a realistic figure would be no more than a maximum 40,000 (Urban 2011, 205-6; Hawkins 2010; Ortega 2011b). Scientology is not recognized as a religion in all the countries where it is present, and over recent decades has come under considerable criticism from scholars, activists, politicians, former members, and journalists concerning, inter alia, specific legal cases of fraud and abuse, dissemination and promotion methods, its status as a religion, claims regarding the scientific status of its doctrines, and the truthfulness of the narratives about Hubbard. ${ }^{6}$

\section{The magazine Advance!}

I have already referenced several argumentations through which Hubbard presented his theories as religious. This issue is the object of much debate; it can be questioned how much such moves were cynical and opportunistic (see Kent 1999 and 1997); it can be asked whether and to what extent Scientology doctrines complemented or in fact contradicted Dianetics; the definition itself of 'religion' needs to be discussed and negotiated before applying it to Scientology. The questions whether Scientology genuinely is a religion or not, and whether its founder's statements were opportunistic, will be treated here as irrelevant; the relevant point is that Scientology was presented as a religion, that it adopted symbols and rituals that resemble those of existing creeds, and that its founder and members propagated theories and narratives that explicitly claimed its continuity with other religions. ${ }^{7}$

6 For an overview see Lewis' Introduction to Lewis 2009a (1-14).

7 The scholars of new religious movements widely recognize that one of the factors of success of such movements is the capacity to create continuity (narrative or visual) with established creeds while at the same time marking its identity and novelty i.e. its superiority. See for instance the discussion in Lewis $2009 \mathrm{~b}$. 
Within Scientology (i.e. among readers who were already members), a major platform for the diffusion of narratives that stressed continuity with other religions was the magazine Advance! launched in 1968. Urban describes it as ' [...] primarily devoted to religion and to comparing Scientology with various other religions [...] concluding that Scientology is the ultimate fulfilment of the spiritual quest embodied in every one of these faiths' (Urban 2011, 164-165). Given the relatively scant scholarly information available about this publication, I have made use of first-hand statements by exScientology members formerly directly involved in its production.

William Burke, an ex-Scientologist who runs the blog Ask the Scientologist, explained:

'The basic format and theme of Advance! was specified by L. Ron Hubbard in confidential documents to the editors. The idea was to compare and contrast Scientology with other, established or historical religions and belief systems. The message was always 'This was an earlier attempt by mankind to solve their problems and advance spiritually. They failed but now Scientology has succeeded in accomplishing what they tried and failed to do.' It was called 'positioning' in the advertising world. You put your product next to the image you want people to have of your product - in this case, real religions' (private e-mail, September 4 2014). ${ }^{8}$

Jefferson Hawkins, ex-Scientologist ${ }^{9}$ and Advance! editor between 1976 (after David Ziff) and 1980, stated that its circulation was approximately 40,000 issues (private e-mail, September 10 2014) and explained:

Hubbard was very much involved in Advance Magazine and dictated exactly the sort of articles that should go into it. He gave an hour lecture to the Advance Magazine Editor (David Ziff at the time) talking about how to put together these 'spiritual history articles.' They were supposed to follow a set formula - there would be a description of the religion or spiritual practice, then it would end with the statement that these people were searching for spiritual knowledge or spiritual freedom, but they failed to reach their

8 In the same e-mail Burke continued: 'Unofficially, in lectures, Hubbard said a lot of nasty things about all other religions, except for Buddhism which he liked to say Scientology was derived from. In one or more lectures he disparages Islam and Muhammad quite badly. Those lectures are definitely NOT available from the Church of Scientology but excerpts have appeared on the Internet'.

9 He left in 2005 and spoke out about Scientology fraud and abuse. See his blog Leaving Scientology. 
goal, and how they would be overjoyed to hear that their spiritual goals can finally be achieved through Scientology. It was an exact set formula. There were many different subjects covered, not only religions, but also things like tarot cards, astrology, divination and so on. [...] Basically, these articles were intended for Scientologists, and were supposed to add credibility and gravitas to Scientology by comparing it to other religions and saying it was superior. These articles were very popular with Scientologists [...] (private e-mail, September 10 2014). ${ }^{10}$

Whereas visual and linguistic Christian references (the adoption of collars, of the cross, expressions such as 'pastoral care') seem to be the predominant method through which Hubbard suggested Scientology's continuity with other religions, allusions to Buddhism also prevailed in published pieces and lectures. This resonated with the narratives concerning Hubbard's journeys to Asia as a young man. For instance, he explicitly compared the concept of thetan liberation to that of the achievement of the state of bodhi. Hubbard even suggested he might be the Mettreya, a 'messianic' figure of Buddhist eschatology in the 'Hymn of Asia' - a poem supposedly composed to celebrate 2,500 years of the Buddhist era (Hubbard 1974 [1956]). However, Hubbard also claimed that Scientology had a goal superior to that of nirvana (which he defined as nothingness) since it aimed at perfecting the individual's knowledge. Even more cursorily, remarks were made by Hubbard regarding the Veda as the ancestors of Scientology and about its affinities with Taoism (Urban 2011, 82-6). Hubbard's competence in things Buddhist, and the accuracy of his specific references, however, have been scrutinized and criticized by scholars. References to the Asiatic religions have been explained, besides biographical influences, as catching up with cultural trends of the times. ${ }^{11}$

We should also remark that Scientology currently claims in its official texts to tolerate and accept other creeds. (Scientology Frequently Asked

10 'I was a Sea Org [i.e. highest-ranking association within Scientology] Member and was working in the promotion and marketing area. I could design (I had a background in commercial art) and could write, so I got the job' (private e-mail, September 10, 2014). 'David Ziff's family owns Ziff-Davis Publishing and is quite wealthy. David decided not to pursue the family business as a career and studied Buddhism and then Scientology. He was a very intelligent man, very bookish, so was a natural for Advance Editor. He was removed in 1976 and sent to the RPF as a supposed 'List One Rockslammer' and I took over as Editor from 1976 to 1980' (private e-mail, September 14 2014).

11 For a thorough and critical discussion of Hubbard's references to Buddhism see Kent 1996 and Kent 1999. 
Questions 2015; Scientology Newsroom 2015.) Moreover, some sympathizers have produced essays and texts that complement Hubbard's claims regarding the continuity with other religions. ${ }^{12}$ Finally, some scholarly texts regarding the observation of Scientology's similarities with other religions have been absorbed by Scientology itself into its discourse by publishing them in official literature. ${ }^{13}$

I have been able to purchase and analyse two issues of Advance! dedicated to Islam: number 33 (1975) and number 43 (1976). ${ }^{14}$ In the following sections I offer an analysis of their iconography and narratives.

\section{Advance! $\mathbf{N}^{\circ} 33$}

\section{Iconography}

I shall analyse the graphic elements in the two issues of Advance! not only because of the synergy of illustration and text in the magazine, but also because some of the pictures ${ }^{15}$ relating to the articles about Islam are presented on page 1 (To the Reader) of Advance! $\mathrm{N}^{\circ} 33$ as belonging to a 'fabulous' series [...] personally photographed by L. Ron Hubbard' ${ }^{16}$ It is stated that he 'is well known internationally as a top photographer [...]. He brings to each subject his characteristic technical mastery based upon years of exact study and experience.' Hubbard as a photographer is further described as truthful, knowledgeable, and understanding, and it is claimed that his 'brilliant work' represents 'a very important new extension in the field of still photography subject control and aesthetics'.

12 See Sawada 1998. I was not able to purchase a copy of Safa 1996.

13 Most notably Wilson 1998.

14 They were located in the Stephen A. Kent and Gordon Drever Collections on Alternative Religions that currently contains: Advance! Issue 1, Vol. I. 1968. Advance! Issue 2, Vol. I; Advance! Issue 3, Vol. I; Advance! Issue 4, Vol. I; Advance! Issue 5, Vol. I; Advance! Issue 6, Vol. I; Advance! 7; Advance! 8; Advance! 9; Advance! 10; Advance! 11; Advance! Issue 12; Advance! Issue 13-164; Advance! Issue 174, 175, 178, 186-193; Advance! Issue 194. 2007; Advance! Special Issue 1998. Alexis Brown has materially explored the collection for me. The collection cannot be claimed to be complete, hence the present investigation can be integrated by further ones. However, it can be stated that the sources here examined are highly significant since they were authored or directly supervised by Scientology's founder and are in widely disseminated materials to Scientologists. Other informants (ex-Scientologists contacted on the net) were unable or unwilling to assist me with their own collections of the magazine.

15 Such pictures are presently in my archives and can be made available to anybody who is interested.

16 Information confirmed by Jeff Hawkins (private e-mail, September 10 2014). 
The picture displays four men sitting cross-legged on a carpet, dressed in stereotypical 'Bedouin' robes with rugs. One in the middle sports a thick and long black beard; he is looking up to the sky. The other three, whom he seems to be directing with a gesture of his left arm, are writing down his words with ink on parchment. In the background three figures seem to be dictating or whispering something to him. One has a sort of paper hat and multicolour wings. We are told that the image represents the moment in which 'The angels reveal God's word (The Koran) to Muhammad who dictates it to his followers'.

The impression is that of a rather amateurishly staged situation, the dresses and props having been improvised. For instance the third standing figure's 'wings' are far from being angel-like and his headgear seems to have been made with cardboard. The turbans and robes rather resemble kitchen towels and curtains. I am not qualified to discuss technicalities in photographic matters; however, in the light of my competence about Islam, I should point out that the picture is not respectful towards its subject: the representation of the Prophet's face is in blatant contradiction with a Muslim taboo.

Further illustrations evoke Islam and the Muslim world. On page 3 is a stylized drawing of a mosque, with the article's title in an 'orientalizing' font; on page 4 is a calligraphy text with the names of God and Muhammad (although the caption only references the former); on page 5 is a miniature of the Prophet represented as faceless and surrounded by a flame that, the caption tells us, signifies His spiritual power.

\section{Narrative}

'The Word of God', an anonymous piece, occupies three pages. ${ }^{17}$ It presents two features typical of Scientology literature in general and of Advance! in particular. First, the extremely pedagogical tone: 'difficult' terms (both English and Arabic, such as 'vestment' and 'jinni' respectively) are explained in footnotes, ${ }^{18}$ and popular misconceptions about Islam (such as the use of the term 'Mohammedanism') are corrected. Second, there is a frequent use of exclamation marks (cf. the title itself Advance! ${ }^{19}$ ); the style of the text sounds

17 Given the limited size of the pieces I shall not indicate page numbers.

18 Complementarily to the usage of a special jargon, Scientology texts systematically insist on the importance of having understood each and every term before proceeding further in learning. See Lewis 2009b, 9.

19 A generous usage of exclamation marks also characterizes Hubbard's novels. 
as if its author wants to acknowledge or induce a sense of wonder felt by the reader approaching such a novel matter (cf. the first sentence: 'A book, a revelation, the direct word of God!'). Exclamation marks are counterbalanced by question marks that highlight the most pedagogical passages ('How did it happen that an illiterate trader from remote southwest Arabia could rise to such eminence?'). The article also displays a taste for 'hard' data, especially in a passage that gives statistics about the verses and words of the Qur'an. Some brief quotations from the Qur'an are also provided.

The narrative is designed to convey the idea of continuity with Scientology, especially after the introductory, 'factual' part. A parallel is suggested between the Prophet and Hubbard, emphasizing that the former 'met the fate of all genuine religious reformers. He was at first jeered, rebuked and attacked by the materialists and vested interests of his day.' It is also stated that idolatry which he fought against, ' $[$...] was big business in ancient Arabia, the AMA [American Medical Association] of its day!' The theological significance of Islam is reduced to two teachings: (i) 'Only the ethical will realize their true spiritual potential'; and (ii) 'Spiritual goals are senior to the craving for sensation or possessions'. Further affinity with Scientology is suggested by recalling the belief that the Black Stone in Mecca was of extra-terrestrial origin. Finally, a rudimentary 'Qur'anic exegesis' is formulated in Scientology jargon. It is explained that 'The Koran was an attempt to introduce a more spiritualized and less anthropomorphic concept of the 8th dynamic', and that in a quoted Qur'anic passage 'God's chronic tone level in this work is from 1.5 - anger - to 2.0 - antagonism!'

Towards the end, the tone of the article abruptly changes. It is claimed that Islam 'failed', since it turned violent and could not cope with modernity: 'in Islamic lands, the authority of the Koran itself is rapidly receding as it fails to provide answers to a space age world.' The conclusion is that 'The Koran was another fascinating milestone in Man's relentless search for the solution to the riddle of his own destiny', but another way has been found: Dianetics and Scientology, which, the author proclaims, have 'brought the dawn'.

Advance! $\mathbf{N}^{\circ} 43$

\section{Iconography}

Advance! $\mathrm{N}^{\circ} 43$ displays three pictures. The cover illustration, by Hubbard, is set in a wood. In front of what seems to be a wooden catapult we see nine 
men. Four of them lie dead - one sports a red cross on his white vestments. The remaining figures are dressed in 'Bedouin-like' robes with turbans. One on the left has just slaughtered one of the men lying on the ground, dressed in white, with a scimitar. Three are raising their scimitars to the sky. A fifth man, on his knees, seems to be examining or plundering one of the victims (his identity is ambiguous).

On the first page, the short text titled Contents states:

The Moslem-Christian wars in the Middle Ages were a bloody chronicle in Man's history. Yet Islam (Mohammedism) which gave world the jihad (holy war) also nurtured, surprisingly enough, a mystical philosophy in in the highest tradition of Man's long search for Truth and Freedom.

A parallel short piece titled To the Reader reads:

[The cover] represents a typical bloody scene from the Crusades. One of the principal battlefields of that period was the area we now call Lebanon. The amazing thing is that a thousand years later the scene is virtually the same. ${ }^{20}[\ldots]$ This is what we call the dramatization of a third dynamic engram.

On page 6 we find another photograph by Hubbard. In a sandy landscape, we see a white-haired, long-bearded figure, barefoot and wearing a white turban, draped in a green tunic, and threatened with rocks and scimitars by younger-looking, stereotypically Bedouin figures who are similarly barefoot and wearing red and white robes. (One of them might actually be holding him up rather than grasping him). In the background we see a black cuboid with a golden stripe. The article and a caption suggest that the picture represents the Prophet of Islam 'persecuted by the religious bigots of his day', and that the black cuboid is the Kaaba. On page 9 an artistic drawing shows three whirling dervishes 'after an illustration in a Persian manuscript'.

\section{Narrative}

The article 'Sufism. The Moslem Search for Truth' was most probably authored by David Ziff (the credits on page 1 report 'leading article by the Editor' and the remaining ones by Hubbard). Whereas its goal, structure, and critical depth are analogous to those of the previous article, it can be

20 The Lebanese Civil War had begun in spring 1975 and would last until 1990. 
said that this one is slightly better crafted and less strident in tone. It begins describing Islam's past greatness, represented by the flourishing of Cordoba in medieval times. The author emphasises that the Muslims exported their civilization to Europe, so 'no one should arrogantly look down on the Moslem peoples', then goes on to distinguish the 'lesser jihad', the historical warfare against the infidels, from the 'greater jihad' or the mystical quest. The latter is described as the 'finest achievement of Islam'. The author recalls the emergence of Sufi mystics and emphasizes that Sufis seek 'Reality' (a term typical of Scientology but here quoted in a Sufi prayer). The author also recalls how Sufism was persecuted in Baghdad. Reference is made to personalities such as al-Hallaj, al-Ghazali, Omar Khayyam and Rumi. The core of Sufi doctrines is summarized as follows: (i) 'Man [...] was trapped by his own ignorance'; (ii) he existed 'in a trapped state'; (iii) he was dominated by the 'lower soul'.

The attempt to establish a resonance with Scientology's doctrines is apparent. It is stated that the Sufis' goal was 'the traditional spiritual goal of personal realization and fulfilment on the eighth dynamic. It's really that simple.' It is emphasized that Sufis rejected academic learning, and insisted on love and ethics. All this is argued with plenty of quotations (whose authors, such as Saadi and Rumi, are cited, but not the precise works).

Sufism is presented as embryonic Scientology; the author states that its chief practice was ' [...] a meditation exercise called remembrance [emphasis in the original] as it consisted of 'remembering' God in a very intense way [...] always done under the guidance of a teacher.' By repeating the phrase 'there is no god but God', the disciple, argues the author, gradually eliminates his attachment to things, replacing it with a love of God. Reference is also made to other contemplative and ecstatic practices, such as dervishes' dances. The article concludes by suggesting that the Sufis were striving to attain the status of OT; however, Sufism failed: 'it didn't have a clue about the reactive mind' and 'its 'tech' [...] would interiorize the individual and eventually spin him in'. The article ends with the statement that the Sufis' dream 'has become our everyday achievement'.

\section{Advance! 33 and 43: possible sources and influences}

An anonymous ex-Scientologist informant has suggested ${ }^{21}$ that a possible source of information for the articles at stake might have been the Story of

21 Private communication in the forum Operation Clambake, September 1-3 2014. 
Civilization by Will Durant (1885-1981), a simplified and popularized history of the world published between 1935 and 1975. Durant, philosopher and historian, covered the Prophet of Islam in the volume The Age of Faith (published in 1950). He presented history as the product of the agency of extraordinary individuals. Hubbard held Durant in high esteem, and dedicated the book on Dianetics to him (Hubbard 1950b). Durant's conception of history and the concept of 'great men' were in line with (and nourished) Hubbard's self-perception. ${ }^{22}$

I have been pursuing this line of investigation by comparing the Advance! article about the Prophet with relevant passages of Durant's Story (Durant 1950). I do not cast any doubts about his overall influence on Hubbard, and I find it likely that he could be one of the sources for such texts. However, the article at stake does not seem to be an edited version of Durant's text (for instance the transcription of Arabic terms and names does not coincide), albeit similar in style and content. Some of the pro-Muslim sentences are too uniquely Muslim in tone and details to be independently written by Hubbard or a non-Muslim; perhaps the text was produced by editing some pro-Muslim material.

On the matter of possible sources I have further addressed Hawkins, who recalled:

The editor would research the subject out of encyclopedias or other books. Hubbard had an old set of Encyclopedia Britannica (1911) and that was used while we were on the ship. I became Advance Editor in 1976, and I used to research these articles at the Clearwater library. (Private communication, September 10 2014.)

I have followed this suggestion and compared the texts at stake with the 1911 Encyclopædia Britannica, but they do not seem to have been directly taken from there.

\section{Other references to Islam}

Hubbard alluded to Islam in other texts, that appeared prior to Advance! In an 'Essay on Management' dated 9 January 1951, the Prophet of Islam is

22 Regarding The Story of Philosophy (1928) by Durant, Gerald Willms writes: '(...) [T]his story contains nearly everything that is basic to Hubbard's anthropological and, moreover, anthropocentric philosophy: the matter/mind problem as one of the most popular themes in the occidental philosophy (...); the principle of pleasure and pain $(. .$.$) as the one and universal$ motive of human action, the (pre-)utilitarian views on utility as virtue, and egoism as reason. The most impressive, sometimes literal source, however, is Durant's Spinoza, especially with regard to the view that mechanical laws of nature have to be applied to the functions of the mind' (Willms 2009, 249). 
evoked as a successful 'manager': 'Nations are so large that until they embark upon conquests they usually have few national goals which embrace all the group [...] Asia Minor, given a goal by Mohammed, exploded into Europe' (Hubbard 1951a, 288). Hubbard expands on the concept of national goals, which, he claims, '[...] are dreamed first by one man, then embraced by a few, and finally held up as the guidon of many.' The Prophet was an instance of this phenomenon, since he ' $[. .$.$] sat alongside the caravan routes until he$ had a goal formulated and his followers managed Mohammedanism into a conquest of a large part of civilization'; an analogous role is attributed to Thomas Jefferson, Christ, and Saint Paul (Hubbard 1951a, 289).

In 'Some Notes on Black Dianetics' (a 'professional lecture' dated September 17, 1951), Hubbard, talking about mental manipulation, cites as an example a narrative about the Persian Hassan-i Sabbāh (1050-1124 CE), the Old Man of the Mountains who led the sect of the Hashshashin or assassins. According to the legend, he had created in his fortress a 'Qur'anic paradise' full of physical pleasures. Select young men were narcotized through hashish (hence the term assassins), and brought to a state where they were induced to believe that they were in paradise and could then be manipulated to kill people in the world outside with the promise they would be welcomed back 'in paradise' again. (Hubbard 1951b, 266-267). The same narrative is briefly alluded to within a similar context in a 'professional course' entitled 'Mysticism', dated February 21952 (Hubbard 1952a, 167-168).

An official Scientology webpage highlights another reference to Islam in 'The Hope of Man,' a lecture given on June 3, 1955: '[The spiritual leaders of the past] handed on a torch of wisdom, of information, generation to generation. It was handed along geographical routes and one of those geographical routes was the Middle East. And one of the people who handed it on was a man named Moses. And again it was handed on to a man named Christ. And he handed it on and even the Arab nations benefited from this through their own prophet, Muhammad. ${ }^{23}$

Anti-Scientology activists are eager to dig out less flattering references by Hubbard to Islam in order to contrast Scientology's alleged continuity with and respect for other faiths. A post entitled 'Scientology Slanders Islam', posted on the anti-Scientology website Operation Clambake by the user 'J. Swift' on June 5, 2009 points to the lecture: 'What's Wrong with this Universe: A Working Package for the Auditor' (9 Dec 1952) and supplies this transcript of an excerpt:

23 See Scientology Newsroom 2015. 
It's [the Black Stone] an enormous stone hanging suspended in the middle of a room, this is an incident called the Emanator by the way, and this thing is by the way the source of the Mohammedan Lodestone that they have hanging down there, that, eh, when Mohammed decided to be a good small-town booster in eh Kansas, Middle-East, or something of the sort. By the way, the only reason he [the Prophet] mocked that thing up [Islam], is the trade wasn't good in his hometown. That's right. You read the life of Mohammed. And he's got a black one and it sort of hung between the ceiling and the floor, I don't know, maybe they call it the Casbah or something or... Anyway, anyway, that thing is a mockup of the Emanator! The Emanator is bright, not black. And so, your volunteer, who insists on a sightseeing trip, goes in and this thing is standing in the middle of the room, and it's going 'wong wong wong wong wong' and he says: 'Isn't that pretty?'. It sure is, and then he says 'Mmmgrmrm ponk' Why, I'll tell you, they cart him from there, and they take him in and they do a transposition of beingness. ${ }^{24}$

We do not need to embark here in a word-to-word exegesis of Hubbard's claims. However we can remark that he seemingly employs 'Kansas' meaning an arid and insignificant place and, more importantly, confuses the term Kaaba with Kasbah, usually designating the citadel or the oldest part of an Islamic city. ${ }^{25}$

The other visual or verbal references to Islam and its Prophet that have been located in the empirical material I have analysed can be regarded as negligible. $^{26}$

24 'J. Swift' 2009. It directs to Hubbard 1952b.

25 The post further reports remarks by Hubbard about the Arab 'race' (20th Advanced Clinical Course, 'Case Analysis-Rock Hunting', August 4, 1958). Finally, it points out that in Footnote 6 Scientology's filing for tax exemption in the US states that, 'Although there is no policy or Scriptural mandate expressly requiring Scientologists to renounce other religious beliefs or membership in other churches, as a practical matter Scientologists are expected to and do become fully devoted to Scientology to the exclusion of other faiths. As Scientologists, they are required to look only to Scientology Scriptures for the answers to the fundamental questions of their existence and to seek enlightenment only from Scientology.'

26 For instance, CSC 1978 contains a paragraph about the Prophet 'who taught that spiritual goals are more important than material goals' as well as a depiction of him; see also CSI 1992, CSI 1998, 2. Remarks about Islam (some of which rather stereotypical and potentially offensive) can be also found in the second and third volumes of Hubbard's series Mission Earth, respectively entitled Black Genesis and The Enemy Within, whose story partly takes place in Turkey. Such remarks are attributed to the series' villain, Soltan Gris, or filtered through his narrative. We read for instance in Black Genesis that a 'turbaned' character explains to him: 'You have to understand the Mohammedan religion. [...] in the Middle East, it is tradition that the children, including boys, are raised in, and have to live in, the harem.' (Hubbard 1986a, 308). In The Enemy Within a character described as 'Moroccan' observes: 'Allah forbids the rendition of live figures' (Hubbard 1986b, 87). 


\section{Scientology and 9/11}

Scientology took a stance about the terrorist attacks of September 11, 2001, attributed to the Islamist terrorist network al-Qaeda, on at least two occasions. In the days immediately following the massacre, Scientologists were actively engaged around the remains of the buildings while allegedly providing the rescue workers with food and psychological assistance. The Church's building on $46^{\text {th }}$ Street was renamed 'Disaster Relief Headquarters', and volunteers were invited to join. This version was given some visibility in the media: The New York Times, while cursorily recognizing that the suspicion of proselytizing lingered over the entire operation (in fact along with food and practical help in the form of a massage often came the proposal of an auditing session), reported the claims of John Carmichael (president of the Church in New York) who emphasised that Scientologists were only 'trying to help' (Waldman 2001). However, anti-Scientology activists, producing intercepted e-mails from Scientologists in New York City, stated that the group was taking advantage of traumatized people and interfering with legitimate mental health practitioners active in the disaster zone. They pointed out that Scientology cynically promoted itself in the media under the name National Mental Health Assistance, very close to that of the organization National Mental Health Association (see Graham 2001). ${ }^{27}$

What is most relevant for the present analysis, however, is that no antiIslamic or Islam-related overtones can be identified in the discourse around this event. In other words, the 9/11 tragedy was not exploited in official Scientology discourse in order to blame Islam.

Eight years later, while recognizing that it was not completely sure that the Egyptian physician and al-Qaeda leader Ayman al-Zawahiri was the person who masterminded the massacre, Dave Figueroa, then president of the Citizens Commission on Human Rights (recognized as a Scientology front group), declared that the terrorist was a psychiatrist (a claim unsupported by any evidence) who manipulated al-Qaeda founder Osama bin Laden through psychiatric practices and (unspecified) drugs (see Edroso 2009, Forsloff 2009, von Marcab 2009).

27 Scientology's involvement in post-9/11 volunteering is also reconstructed in Cusack and Digance 2009. I was surprised to see that the authors, albeit admitting that it had not been possible to discover how exactly Scientology was granted permission 'to undertake such a high-profile role' (Cusack and Digance 2009, 437) do not mention any criticism of the initiative, not even in the interest of scholarly completeness. 


\section{Scientology and the Nation of Islam}

Scientology is also associated with Islam in the context of the adoption of Dianetics by the Nation of Islam (NOI), a religious black-nationalist group adhering to Islam and founded in Detroit in 1930 by Wallace Fard Muhammad (1893-? [disappeared in 1934]). He was presented and perceived, inter alia, as the Islamic Mahdi or Prophet (or even Allah) ${ }^{28}$ NOI's leader Louis Farrakhan (b. 1933), who allegedly recognized in 2005 the beneficial effects of Dianetics on a NOI minister in Los Angeles called Tony Muhammad, started encouraging followers in 2010 to take auditing and to become Scientology auditors. According to NOI's official newspaper the Final Call, in 2012 more than 1,000 members had become certified auditors and another 4,000 were studying 'some aspect of Scientology' (Gray 2012). Farrakhan was unconcerned with the fact that Hubbard was white (and at best uninterested in the social causes promoted by NOI if not blatantly racist); he regarded Dianetics as a useful technology, 'a tool that I can use to help our people' (Hallowell 2012). ${ }^{29}$

All this resonated with a Scientology policy aimed at proselytizing among black communities that included founding churches in Harlem and Inglewood, California, as well as discounts for NOI members (Gray 2012). It has been suggested that NOI and Scientology already enjoyed some affinity. NOI's beliefs also include UFO-related narratives (such as that a 'Mother Plane' is alluded to in the Book of Ezekiel ${ }^{30}$ ) and greatly emphasises selfimprovement. Moreover, NOI similarly perceives itself as under attack by malignant media (Gray 2012). ${ }^{31}$

\section{Interpretation}

What would Hubbard choose from the Islamic basket? We can now draw some observations and extrapolations from the empirical material observed so far.

\footnotetext{
28 '12. WE BELIEVE that Allah (God) appeared in the Person of Master W. Fard Muhammad, July, 1930; the long-awaited 'Messiah' of the Christians and the 'Mahdi' of the Muslims' (Nation of Islam 2015).

29 In her autobiographical Little X. Growing Up in the Nation of Islam author Sonsyrea Tate recalls 'Ma [...] would later become a minister in the Church of Scientology, explaining that its philosophies in no way contradict those of Islam. She preaches universal love and universal understanding and forgiveness now' (Tate 1997, 227).

30 See Elijah Muhammad 2010 [1973].

31 For a polemical viewpoint see Ortega 2001a. For media coverage on part of NOI's newspaper see Muhammad 2013, Muhammad 2012, Muhammad 2011. See also Warikoo 2013.
} 
From the 1950s onwards, Hubbard was emphasizing that Scientology was a religion. In Hjärpe's parlance we might state that he was constructing a 'Scientology basket'. One might be tempted, following Hjärpe's image, to argue that Hubbard basically was taking from Islam the very 'basket' he needed - the 'religious container' - in order to present Scientology itself as a religion. However, this statement, upon closer inspection, appears simplistic, since in fact it is not simply claimed Scientology continues and complements the Islamic revelation. In the articles examined here, the argumentation followed by Hubbard is based on a more complex dialectic.

On the one hand Islam is 'exoticized' and provided with an aura of antiquity and fascinating 'otherness' that Hubbard can draw upon, thus allowing Scientology to enjoy the same aura. This 'exoticization' is not necessarily and completely intentional; it can be also seen as depending on Hubbard's (and the Scientologists') non-scholarly understanding and amateurish information about Islam, clearly indicated by elements such as the inconsistent oscillation between the usage of the terms Mohammedanism/Islam, the confusion of the terms Casbah/Kaaba, and the depiction of the Prophet's face (outrageous for a Muslim readership). Furthermore, it can be argued that Islam was in any case liable to be perceived as exotic per se, like any non-Western religion, by Hubbard's readership in the 1970s. The exotic/exoticizing character of the 'Islamic basket' exploited by Hubbard can be better understood if we recall that he also adopted Christian-like symbols, which had more of a normalizing function for his audience (i.e. they conveyed a religious aura but they were also identical or similar to other symbols that an American public was accustomed to).

From another point of view, Islam is made relevant for Scientology (and modernity) by emphasizing its alleged 'scientific'/Scientological elements (i.e. both its scientific supremacy and the alleged presence of ethical and epistemological intuitions later developed by Dianetics and Scientology).

In the texts (and pictures) examined, Islam is presented both as an ennobling and exoticizing canopy for Scientology and as a form of spirituality that anticipated Scientology itself, a 'Scientology of old': Scientology is religionized in Islamic garb, and Islam is 'Scientologicized.' Such a dialectic is constantly present in the texts analysed here, and according to scholarly studies (and in line with my informants' observations) seems analogous to the use made by Hubbard of other non-Western religions such as Buddhism. Sticking to Hjärpe's metaphor here proves rather difficult; we might say that Scientology is placed in the Islamic basket and vice versa, simultaneously. 
Other, more specific items of the 'Islamic basket' seem to be placed into the 'Scientology basket' in accordance with this dialectic. One is the Prophet, who is presented as a religious, exotic figure but also as a contemporary 'manager' when reading it through Durant's philosophy. Another item is the lesser jihad presented as a partially successful 'enterprise'. Interestingly the jihad was not evoked as a threat for the West as it currently happens in Islamophobic discourse (that often fails to distinguish between a lesser and greater one). Also this is probably seen as a reflection of the times. Islamophobia was possible but it was not necessary.

As mentioned in the introductory paragraphs, the question 'What would Ron choose from the Islamic basket?' can also be interpreted as a question about Scientology's theological developments and PR strategies.

In scholarly analysis, one should not engage in future-telling, especially if the theoretical framework chosen is non-confessional and nominalistic, as Hjärpe's is. We should set no limits to the creativity of theologians. However it is of some interest to debate the extent to which Scientologists might be willing and able to intervene in Scientology's beliefs and ideas (i.e. to place or take items in and out from their 'basket' $)^{32}$ while presenting themselves to potential converts and interlocutors with a non-Western and non-Christian cultural/religious background.

It is at present unclear whether Scientology has the capacity (or the ambition) to expand in Muslim countries. ${ }^{33}$ However, such a case might be Turkey, which is close to Europe and also economically developed enough to constitute an interesting market. ${ }^{34}$ The encounter of Scientology with the

32 For a discussion of the most central beliefs of Scientology see Christensen 2009a.

33 Issue 298 of the Scientology publication The Auditor reports a short piece about Scientology being introduced to the Toronto Iranian Community by Auditor Vaheed Jaberanasari (Anonymous Auditor Scientologist Undated). Through anti-Scientology related mailing lists and websites I could read articles regarding occasional collaboration between Scientology and Turkish Muslims in Germany in the late 1990s, as well as about short-lived propositions to Muhammar Gaddafi, and a rejected attempt of a collaboration proposal with the Grand Mufti of Russia in 2001 (see Clamato 2001). No further info about such events could be located. However such episodes seem to involve more financial/juridical/political issues than doctrinal discussions. 34 There seems to be a very limited presence. A newspaper article (Akbaş 2007) claims that Scientologists came to Turkey during the earthquake in 1999. The Turkey representative of the Church of Scientology Umut Duman (see Duman 2004) told the newspaper that upon his invitation, four representatives of the Scientology humanitarian organization Volunteer Ministers came to the earthquake affected area and registered around 500 Turks. Duman is also quoted as saying that there are around 30 active members in Turkey, and that efforts are made to translate Scientology works into Turkish. Another newspaper article (Anonymous Habertürk Reporter 2008) claims that four recruitment agencies linked to the Church of Scientology have been established in Turkey. 
Nation of Islam is another example in the wider context of a non-Middle Eastern country. Another scenario is the one in which Scientologists officially claim a compatibility with Islam in order to be accepted as credible interlocutors in a dialogue of religions, or at least to uphold the weaker claim according to which Scientology is respectful towards other religions. ${ }^{35}$ In fact Islam-related official statements made over the past years seem to be rather limited to the declared advocacy of religious tolerance (the refusal to view 9/11 in Islamophobic fashion should be read in this perspective, channelling criticism instead towards the traditional polemical object of Scientology - the psychiatric establishment).

Which of the items in the basket might be useful, and what could or should be discarded? While arguing for Scientology's compatibility or affinity with Islam, the vagueness of its concept of God (the eighth dynamic) (see Bednarowski 1989, 63) could be both an advantage (i.e. as another lesser 'basket' available to be filled with concepts sympathetic for potential new members) and a disadvantage (Muslims could precisely claim that they already entertain a much more articulated concept of God). The idea of reincarnation doesn't seem reconcilable with Islam. Another potential disadvantage in a specifically Middle-Eastern and traditionally Muslim context is that Scientology as a whole may be negatively identified by critics as quintessentially Western and indeed specifically American. Analogous considerations hold for the Christian-like elements in Scientology's language, symbols, and rituals.

I have already highlighted the absence of blatantly Islamophobic official statements in recent years, even in contexts that could have inspired them; Scientologists might capitalize on this and contrast it with the less friendly official statements about Islam made within other religions. There are, however, other statements made both by the founder and by other Scientology-related authors which can be seen as stereotyping, inaccurate, or even offensive, and these should also be taken into account. In all of the aforementioned scenarios they potentially undermine not only Scientology's claim of a theological affinity/compatibility but also its claim regarding tolerance and respect for Islam, not to mention the scholarly credibility of those who make such claims.

Specifically concerning the encounter with the Nation of Islam, we should note that the way that Islamic beliefs are interpreted within a movement like

35 The Mayor's Interfaith Council in Washington, DC did include at least one representative of Scientology, Reverend Susan Lee Taylor between 2011 and 2013 (for its functions and members see Mayor's Office of Religious Affairs, Undated). 
this one are regarded as deviant or heretical by the majority of Muslims. Moreover, what we see in it is at most a pragmatic convergence with the practice of Dianetics: so far no theological synthesis has been proposed, doctrinal discussion being limited to the statements by Louis Farrakhan cited above. Hence, we should be cautious in assuming that the adoption of Dianetics by NOI can be seen as a 'prototypic experiment' in the fusion or encounter of their respective beliefs, with any potential for application on a larger scale. Such encounter as has occurred is due to Farrakhan's initiative, and may well fade away after a change in leadership. Yet if anything can be learned from such alliance, it is that in order for Scientology to attract Muslim believers or communities, a winning strategy might be to eliminate from the 'basket' most of the specifically religious items and leave the 'scientific' ones. In other words, Scientology might succeed in a Muslim environment by shrinking back to Dianetics.

STEFANO BIGLIARDI teaches Philosophy, Critical Thinking and Ethics at Monterrey Tech, Campus Santa Fe (Mexico City). He served as a postdoctoral researcher at Center for Middle Eastern Studies, Lund University. E-Mail: stefano.bigliardi@cme.lu.se

\section{Bibliography}

\section{Primary material}

(Including press articles and scholarly articles published in Scientology literature; all webpages have been accessed for a final check on May 26, 2015)

\section{Akbaş, Tutkun}

2007 Scientology tarikatının ünlü Türk müritleri var. - Sabah, July 1st <http://arsiv.sabah.com.tr/2007/07/01/haber,177DE27EA9F74113B69 AF0E82E8C343B.html>.

\section{Anonymous Advance! Scientologist}

1975 The Word of God. - Advance! 33; 3-5 and 11.

\section{Anonymous Advance! Scientologist [David Ziff?]}

1976 Sufism. The Moslem Search for Truth. - Advance! 43, 6-9 and 10.

\section{Anonymous Auditor Scientologist}

N.d. ASHO Tour Sparks Volunteer Minister Activity in Muslim Community. - The Auditor 298, 6. 


\section{Anonymous Habertürk Reporter}

2008 Sosyete tarikatı Türklerin peşinde! - Habertürk, January $18<\mathrm{http}: / /$ www.haberturk.com/dunya/haber/51375-sosyete-tarikati-turklerinpesinde>.

\section{Church of Scientology International [CSI]}

1992 What is Scientology? Los Angeles: Bridge Publications, Inc.

1998 Scientology. Theory and Practice of a Contemporary Religion. Los Angeles: Bridge Publications, Inc.

Church of Scientology of California [CSC] (Based on the works on L. Ron Hubbard)

1978 What is Scientology? Los Angeles: Church of Scientology of California.

'Clamato' [Contributor to the web site Operation Clambake]

2001 What Other Religions Think of Scientology <http://ocmb.xenu.net/ ocmb/viewtopic.php?t=3953>.

\section{Duman, Umut}

2004 Umut Duman's Personal Website < http://scientologist.myhomepage. org/umutduman/index.htm>.

\section{Durant, Will}

1950 The Age of Faith. New York: Simon \& Schuster.

\section{Edroso, Roy}

2009 Scientologist Reveals 'Psychiatry' Made Osama Do 9/11. - The Village Voice, February $9<\mathrm{http}: / /$ blogs.villagevoice.com/runninscared/2009/02/scientologist_r.php $>$.

\section{Elijah Muhammad}

2010 [1973] Ezekiel's Prophecy of The Wheel [Extracted from Fall of America, 1973] <http://www.finalcall.com/artman/publish/Columns_4/ article_6852.shtml>.

\section{Forsloff, Carol}

2009 Scientologist Proclaims 9/11 Attacks Result of Psychiatry. - Digital Journal, February 8; Available at <http://www.digitaljournal.com/ article/266842>.

\section{Graham, Barbara}

2001 Scientology at Ground Zero. - Operation Clambake, September 18 $<$ http://www.xenu.net/archive/events/20010911-tragedy/>.

\section{Gray, Eliza}

2012 The Mothership of All Alliances -New Republic, October $5<\mathrm{http}: / /$ www.newrepublic.com/article/politics/magazine/108205/scientologyjoins-forces-with-nation-of-islam>. 


\section{Hallowell, Billy}

2012 Farrakhan Defends Integration of Scientology's Dianetics Into Nation of Islam Theology: 'A Tool That I Can Use to Help Our People.' - The Blaze, September $30<\mathrm{http}: / /$ www.theblaze.com/stories/2012/09/30/ farrakhan-defends-integration-of-scientologys-dianetics-into-nationof-islam-theology-a-tool-that-i-can-use-to-help-our-people/>.

\section{Hawkins, Jefferson}

2010 So How Big is the Church of Scientology Really? - Leaving Scientology, March 27 <http://leavingscientology.wordpress.com/2010/03/27/ so-how-big-is-the-church-of-scientology-really/>.

Hubbard, L. Ron.

1950a Dianetics: The Evolution of a Science. -Astounding Science Fiction 45 (3), 43-87.

1950b Dianetics. The Modern Science of Mental Health. New York: Paperback Library.

1951a An Essay on Management. - id. 1983. The Research and Discovery Series. A Running Record of Research into the Mind and Life. Volume 5, 287-304. Los Angeles: Bridge Publications; Copenhagen: New Era Publications.

1951b Some Notes on Black Dianetics. - id. 1984. The Research and Discovery Series. A Running Record of Research into the Mind and Life. Volume 5, 261-274. Los Angeles: Bridge Publications; Copenhagen: New Era Publications.

1952a Mysticism. - id. 1989. The Research and Discovery Series. A Running Record of Research into the Mind and Life. Volume 10, 153-170. Los Angeles: Bridge Publications; Copenhagen: New Era Publications.

1952b What's Wrong with this Universe: A Working Package for the Auditor (Recorded lecture) <http://www.ami.com.au/ bradw/cos/Sounds/ casbah.wav>.

1974 [1956] The Hymn of Asia. Los Angeles: Church of Scientology of California, Publications Organization.

1986a Mission Earth: Black Genesis. Los Angeles: Bridge Publications.

1986b Mission Earth: The Enemy Within. Los Angeles: Bridge Publications.

\section{'J. Swift' [Contributor to the web site Operation Clambake]}

2009 [Posted June 5; last edited September 24, 2010] Scientology Slanders Islam <http://ocmb.xenu.net/ocmb/viewtopic.php?t=30756>.

\section{von Marcab, Lilly}

2009 Scientology: Psychiatrists to Blame for 9/11 Attacks. - RushPRNews, February 5 <http://rushprnews.com/2009/02/05/scientology-psychiatrists-to-blame-for-911-attacks/>.

\section{Mayor's Office of Religious Affairs}

N.d. [Information regarding the period 28 July 2011 - 29 July 2013] Mayor's Interfaith Council<http://ora.dc.gov/page/mayors-interfaith-council>. 
Muhammad, Ashahed M.

2013 Nation of Islam Auditors graduation held for third Saviours' Day in a row. - The Final Call, February $28<\mathrm{http}$ ://www.finalcall.com/artman/ publish/National_News_2/article_9651.shtml>.

\section{Muhammad, Charlene}

2012 A Weekend of Healing at Mosque Maryam. -The Final Call, July 5 $<$ http://www.finalcall.com/artman/publish/National_News_2/article_9004.shtml>.

2011 Nation Adopts New Technology to Serve Black Nation, World. The Final Call, April 4 <http://www.finalcall.com/artman/publish/ National_News_2/article_7697.shtml>.

Nation of Islam.

2015 The Muslim Program <http://www.noi.org/muslim-program/>.

Ortega, Tony.

2011a Scientology and the Nation of Islam: A Heartwarming Independence Weekend Parable. - The Village Voice, July $1<\mathrm{http}$ ://blogs.villagevoice. com/runninscared/2011/07/scientology_and_1.php>.

2011 b Scientologists: How Many of Them Are There, Anyway? - The Village Voice, July 4 <http://blogs.villagevoice.com/runninscared/2011/07/ scientologists_1.php>

\section{Safa, Hajj Muhammad al-Qaiim}

1996 Scientology and Islam: An Analogous Study. Los Angeles: Freedom Publishing.

\section{Sawada, Fumio}

1998 The Relationship between Scientology and Other Religions. - CSI, Scientology. Theory and Practice of a Contemporary Religion, 225-233. Los Angeles: Bridge Publications, Inc.

\section{Scientology Frequently Asked Questions}

2015 What is the Scientology View Regarding Other Religions? <http:// www.scientology.org/faq/scientology-beliefs-and-practices/scientology-and-other-religions.html>.

\section{Scientology Newsroom}

2015 What is Scientology's View of Moses, Jesus, Muhammad, the Buddha, and Other Religious Figures of the Past? <http://www.scientologynews.org/faq/scientology-view-moses-jesus-mihammad-buddha. html>.

Tate, Sonsyrea

1997 Little X. Growing Up in the Nation of Islam. San Francisco: HarperCollins. 


\section{Waldman, Amy}

2001 Changed Lives. Religious Leader Takes His Call to Ground Zero. - The New York Times online, September $20<$ http://www.nytimes. com/2001/09/20/nyregion/changed-lives-religious-leader-takes-hiscalling-to-ground-zero.html $>$.

\section{Warikoo, Niraj}

2013 Nation of Islam Convention Returns to Detroit with Message of Discipline, Self-reliance. - Detroit Free Press, February $19<$ http://www. freep.com/article/20140219/NEWS05/302190040/Nation-of-Islamconvention-in-Detroit-Farrakhan>.

\section{Wilson, Bryan Ronald}

1998 Scientology. An Analysis and Comparison of its Religious Systems and Doctrines. - CSI, Scientology. Theory and Practice of a Contemporary Religion, 111-145. Los Angeles: Bridge Publications, Inc.

Blogs and Web pages mentioned

William Burke: Ask the Scientologist <https://therealaskthescientologist. wordpress.com/>.

Jefferson Hawkins: Leaving Scientology <https://leavingscientology.wordpress.com/>.

Andreas Heldal-Lund: Operation Clambake<http://www.xenu.net/>.

\section{Scholarly literature}

\section{Bednarowski, Mary Farrell}

1989 New Religions and the Theological Imagination in America. Bloomington and Indianapolis: Indiana University Press.

\section{Christensen, Dorthe Refslund.}

2009a Scientology and Self-Narrativity: Theology and Soteriology as Resource and Strategy. - James R. Lewis (ed), Scientology, 103-116. New York and Oxford: Oxford University Press.

2009b Sources for the Study of Scientology: Presentations and Reflections. - James R. Lewis (ed), Scientology, 411-431. New York and Oxford: Oxford University Press. 


\section{Cusack, Carole M. \& Justine Digance}

2009 Pastoral Care and September 11: Scientology's Nontraditional Religious Contribution - James R. Lewis (ed), Scientology, 435-437. New York and Oxford: Oxford University Press.

\section{Dericquebourg, Régis}

2009 How Should We Regard the Religious Ceremonies of the Church of Scientology? - James R. Lewis (ed), Scientology, 165-182. New York and Oxford: Oxford University Press.

Harley, Gail M. \& John Kieffer

2009 The Development and Reality of Auditing. - James R. Lewis (ed.), Scientology, 183-205. New York and Oxford: Oxford University Press.

Hjärpe, Jan

1997 What Will Be Chosen from the Islamic Basket? - European Review 5 (3), 267-274.

Kent, Stephen A.

1996 Scientology's Relationship with Eastern Religious Traditions. - Journal of Contemporary Religion 11(1), 21. <http://www.bible.ca/scientologyeastern-religions-Kent.htm>.

1997 Scientology-Is This a Religion? - Marburg Journal of Religion 4 (1), 1-23. <http://www.bible.ca/scientology-not-religion-kent.htm>.

1999 The Creation of 'Religious' Scientology. - Religious Studies and Theology 18 (2) (Dec. 1999), 97-126. <http://web.archive.org/ web/20090211030604/http://www.holysmoke.org/cos/kent-fakereligion.htm $>$.

Lewis, James R. (ed)

2009a Scientology. New York and Oxford: Oxford University Press.

\section{Lewis, James R.}

2009b The Growth of Scientology and the Stark Model of Religious 'Success.' - James R. Lewis (ed), Scientology, 117-140. New York and Oxford: Oxford University Press.

\section{Rothstein, Mikael}

2009 His name was Xenu. He used renegades...': Aspects of Scientology's Founding Myth. - James R. Lewis (ed), Scientology, 365-387. New York and Oxford: Oxford University Press.

\section{Urban, Hugh B.}

2011 The Church of Scientology: A History of a New Religion. Princeton, NJ: Princeton University Press.

\section{Wallis, Roy}

1976 The Road to Total Freedom. A Sociological Analysis of Scientology. London: Heinemann. 


\section{Willms, Gerald}

2009 Scientology: 'Modern Religion' or 'Religion of Modernity'?' - James R. Lewis (ed), Scientology, 245-265. New York and Oxford: Oxford University Press. 
